\begin{tabular}{|c|c|c|}
\hline 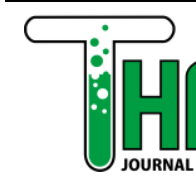 & TURAL SCIENCE TEACHING & $\begin{array}{l}\text { Thabiea : Journal of Natural Science Teaching } \\
\text { Vol. 4(2), pp. } 159-169,2021 \\
\text { Available online at } \\
\text { http://journal.iainkudus.ac.id/index.php/Thabiea } \\
\text { p-issn: } 2580-8474 \text {, e-issn: } 2655-898 X\end{array}$ \\
\hline
\end{tabular}

\title{
Students' Environmental Literacy: Environment Education Assisted E-Booklet on Biodiversity Gegas Dam Indonesia Context
}

\author{
Euis Nursa'adah ${ }^{1 *}$, Budi Maryani ${ }^{2}$, Aceng Ruyani ${ }^{1}$ \\ 1, Graduate School of Science Education, University of Bengkulu, Bengkulu 38371, Indonesia \\ ${ }^{2}$ SMA Negeri 11 Musirawas, Sumatera Selatan, Indonesia \\ *Correspondence: euis@unib.ac.id
}

\begin{tabular}{ll}
\hline Keywords: & Abstract \\
Environtmental, & Indonesia is one of the world's mega biodiversity needs to be preserved, due to estimated \\
Literacy, & the extinction rate of one species is estimated at 10,000 times per year caused by human \\
Education, & activity. Various efforts have been made by various sectors to preserve the environment, \\
Bodiversity, & including in education through Environmental Education (EE). This research aim to \\
e-Booklet & implement Environmental Literacy (EL) domain in Biodiversity learning assisted \\
& validated e-booklet (CVR0,67) to enhance student knowledge, cognitive skills \\
& (identification of issues, analysis of issues, and action plans), attitude (verbal \\
& commitment, environmental sensitivity, and feelings towards the environment), and \\
& responsible behavior towards the environment. The EL domains related to real context \\
& of biodiversity in Gegas Dam is implemented in order to avoid the availability of \\
& disconnecting youth generation with their native biodiversity. Data analysis and \\
& identification of diversity- diversity index, homogeneity, dominance and correlation \\
& among chemical-physical environmental factors- are presented in an e-booklet to \\
& strengthen students' knowledge and cognitive skills, while attitude and responsibility \\
& behavior are strengthened by presenting local, national and global environmental issues. \\
& Through one group pre-posttest design, 30 high school students in South Sumatra as \\
& youth generation were involved in this research. Students' EL is measured by 66 \\
& questions EL domain. The results showed that students' verbal commitment got the \\
highest n-gain score (0.62 medium), while environmental sensitivity was the smallest & (0.2 low). These results indicate that verbally students or youth generation already know \\
how to conserve the environment. Cultivation of environmental conservation habits \\
could be continuously improved by realizing their verbal ideas.
\end{tabular}

To cite this article:

Nursa'adah, E., Maryani, B., Ruyani, A. (2021). Students' Environtmental Literacy: Environment Education Assisted E-Booklet on Biodiversity Gegas Dam Indonesia Context. Thabiea : Journal of Natural Science Teaching, 4(2), 159-169.

\section{Introduction}

Biodiversity define as variability among living organisms from various sources, including from interalia, terrestrial, forest, marine ecosystems, and many others involving complex ecology. Diversity among species, species and ecosystems is also biodiversity. In addition, biodiversity refers to ethical, economic, and social dimensions that are interrelated with biodiversity (Hooykaas et al., 2019).

Based on the variability of living things and ecosystems in Indonesia, It is categorized as one of the world's centers of biodiversity known as mega biodiversity. Biodiversity in Indonesia is classified into flora and fauna. One of the fauna diversity involving marine or aquatic ecosystems is the diversity of fish. More than 8500 types of fish live in Indonesian waters (45\% 
of all fish species in the world), and 1300 of these fish species live in freshwater. It is just the potential of Indonesia's biodiversity is accompanied by the threat of its decline. It is estimated that the decline rate of a species per year to be 10,000 times faster than usual (Koneri, 2019). The condition is caused by many factors, fragmentation, habitat degradation (including pollution), global climate change, overuse of species for human interests, invasive of foreign species, and increasing the spread of disease. Meanwhile, the threat of extinction of marine ecosystems such as fish in Indonesian waters is caused by pollution, irrigation projects, invasion of foreign species, overfishing and using destructive methods (poison, electricity, bombs) and habitat destruction, there are 14 species of freshwater fish threatened decline in Sumatera Island (Wargasasmita et al., 2002). In addition, water quality decrease is also one of the factors causing the declining diversity of species in freshwater (Ismail, 2104).

It is known human activity is the main factor causing the decline of biodiversity. Therefore, efforts are needed to maintain biodiversity to avoid extinction. If not been done, humans have no chance to interact with it. Besides biodiversity conservation efforts are essential, involving the community is also important. It will be the foundation for protecting the environment. Concept of involving the community in education is known as biodiversity learning as part of Environmental Education (EE). EE is a conservation strategy that creates a synergy space, facilitating scientists, decision-maker, and communities, and users to maintain environment that imparts knowledge, values, and practices (Ardoin et al., 2020).

The importance of EE has been recognized since its inception and youth involvement in environmental decision-making (Hollweg et al., 2011). Through learning biodiversity, it expects to equip students or youth the Environmental Literacy (EL)- cognitive skills, attitude, and environmentally responsible behavior (Hollweg et al., 2011) and (Kaya \& Elster, 2018) to enhance their competencies in analyzing, solving biodiversity problems, having attitudes sensitivity and feeling- and behaviors of EL. Therefore, EE will be able to contribute to environmental conservation and quality, considering that EE is not only a transformation of knowledge but also provide attitudes and skills to protect the environment, as previously stated.

Implementation of EE is conducted in several countries long period, monitored continuously, and inserted environmental behavior effectively (Craig \& Allen, 2015; Deniz Saribas et al., 2014; Goldman et al., 2018; Goldman et al., 2014; Hooykaas et al., 2019; Shamuganathan, 2015; Saltan \& Divarci, 2017). The results show that students are able to express responsibility towards the environment. This indicates that EE provides many good opportunities to maintain the environmental sustainability.

Several studies analyzing EL content at the school level have been conducted (Karimzadegan \& Meiboudia, 2012) and (Srbinovski et al., 2010). The results show that EL is not well listed in elementary school books. Knowledge is more focused than environmentally responsible attitudes and behaviors. Furthermore, the EL of teachers and prospective teachers and their beliefs in teaching EE were analyzed (D Saribas, 2015) and (Timur et al., 2013); EL to enhance Education for Sustainable Development (Wilujeng et al., 2019) and booklet (Imtihana, M., et al., 2014). The results show that the EL for prospective teachers is at a moderate level. Pre-service teachers who major in the environment has better EL than those who are not environmental majors. In addition, teachers did not have adequate environmental knowledge so they did not have confidence in teaching EL. 
Indonesian school curriculum has facilitated and determined the application of EE and biodiversity through curriculum content which requires students to analyze various of biodiversity in Indonesia and their threats, conservation and monitoring of their preservation. Based on previous researches and Indonesian curriculum document, it is known that the development of EE is able to have a good impact on the EL of students or prospective teachers in maintaining an environment that also supports sustainable development programs. Providing EL domain in teaching materials will help students and teachers get a better knowledge of EL which is the basis for attitude and responsibility towards the environment. In this study, EE was implemented with a booklet designed based on the EL domain. Biodiversity Gegas Dam is used as an actual context in this research. It is located in South Sumatra Province, which is a freshwater fishery conservation area.

The EL domain consists of domain knowledge, cognitive skills (identification of issues, analysis of cases and action plans), attitude (verbal commitment, environmental sensitivity, and feelings towards the environment), and responsible behavior towards the environment. Data analysis and identification of diversity- diversity index, homogeneity, dominance and correlation among chemical-physical environmental factors- are presented in an e-booklet to strengthen students' knowledge and cognitive skills, while attitude and responsibility behavior are reinforced by offering local, national and global environment issues.

\section{Method}

The research was conducted using a Research and Development Design (Figure 1) to design an e-booklet and implemented biodiversity learning that provides EL with e-booklets.

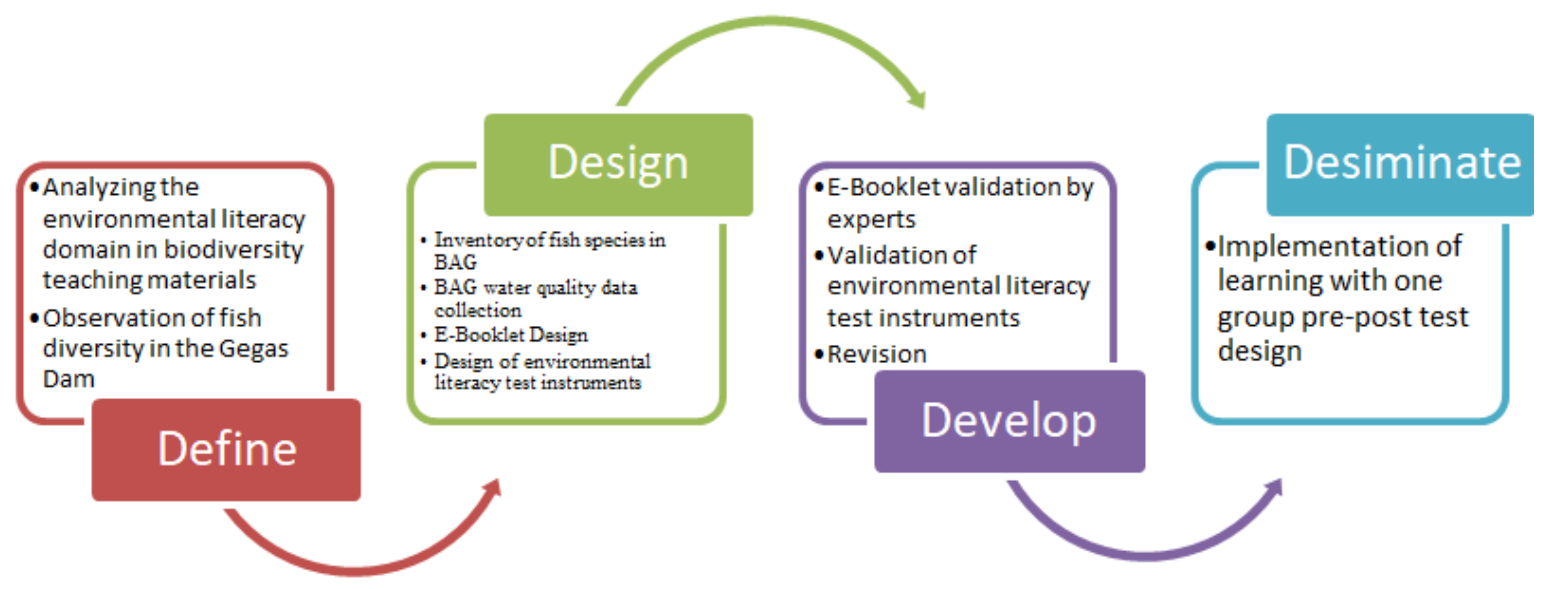

Figure 1. Research Design

The e-booklet design is according to the EL domains and real biodiversity context by following steps:

1) Analyzing the environmental literacy domain in biodiversity teaching materials

2) Observation of fish diversity in the Gegas Dam

3) Measuring the index of fish species diversity, homogeneity, dominance, and the relationship between water quality and fish diversity in each Gegas Dam station.

4) Measuring water quality - $\mathrm{pH}$, turbidity, $\mathrm{DO}, \mathrm{BOD}, \mathrm{COD}$, and temperature-

5) Mapping the environmental literacy domain, biodiversity content and the context of biodiversity in the Gegas Dam in an e-booklet. 
The e-booklet validates by experts and the content validity ratio calculation to determine the validity of the e-booklet. Instrument for measuring students' EL domains is modified from the National Environmental Literacy Assessment (NELA) which has been adapted to biodiversity content and context. Language, contents, and indicators of EL domains are validation aspects. General standards for EL instruments are present in Table 1.

Table 1. Criteria of Environmental Literacy Instrument

\begin{tabular}{|c|c|c|c|}
\hline Environmental Literacy Domain & Specific Component & Questions Nr & Sum \\
\hline Knowledge & Ecological knowledge & $1-20$ & 20 \\
\hline \multirow[t]{2}{*}{ Attitude } & Verbal commitment & $21-32$ & 12 \\
\hline & Environmental Sensitivity & $33-42$ & 10 \\
\hline \multirow{4}{*}{ Competence (Cognitive Skill) } & Feels of Environmental & $43-44$ & 2 \\
\hline & Identify of Issue & $45,46,47$ & 3 \\
\hline & Analysis of Issue & $49-54$ & 6 \\
\hline & Action plan & 48 & 1 \\
\hline \multirow[t]{2}{*}{ Behavior } & Pro Environmental Action & $55-66$ & 12 \\
\hline & & & 66 \\
\hline
\end{tabular}

The implementation of EE on the biodiversity of Gegas Dam assisted by e-booklets was conducted with a one group pre-post-test design. The pre and post-test data were analyzed to describe the increase in the specific components of the EL domain. Overall, types of instruments used at each stage of this research activity are present in Table 2.

Table 2. Research Instruments

\begin{tabular}{|c|c|c|c|}
\hline No & Instruments & Data and Analysis & Sources \\
\hline \multicolumn{4}{|c|}{ Define } \\
\hline 1 & $\begin{array}{l}\text { Parameter observation uses to analyze } \\
\text { the EL domain in biodiversity teaching } \\
\text { materials and fish diversity in the Gegas } \\
\text { Dam. }\end{array}$ & $\begin{array}{l}\text { Descriptive data about } \\
\text { environmental literacy domain in } \\
\text { biodiversity teaching material }\end{array}$ & $\begin{array}{l}\text { Biodiversity teaching } \\
\text { material }\end{array}$ \\
\hline 2 & Parameter of Interview & Interview transcript & $\begin{array}{l}\text { Fishermen in Gegas } \\
\text { Dam }\end{array}$ \\
\hline \multicolumn{4}{|c|}{ Design } \\
\hline 3 & Observation form & $\begin{array}{l}\text { Diversity index, homogeneity, } \\
\text { and dominance }\end{array}$ & Gegas Dam \\
\hline 4 & Material for measure water quality & Water quality & Gegas Dam \\
\hline \multicolumn{4}{|c|}{ Develop } \\
\hline 5 & e-booklet & e-booklet validated & e-booklet \\
\hline 6 & EL test & EL test validated & EL test \\
\hline \multicolumn{4}{|c|}{ Disseminate } \\
\hline 7 & EL test & Students' EL domain & Students \\
\hline
\end{tabular}




\section{Results and Discussion}

\section{Analysis the Environmental Literacy Domain in Biodiversity Teaching Materials}

The results of the analysis teaching materials related to the EL domain in the topic of biodiversity from several teaching materials in school level are presented in Table 3.

Table 3. Analysis Environmental Literacy Domain in Teaching Material

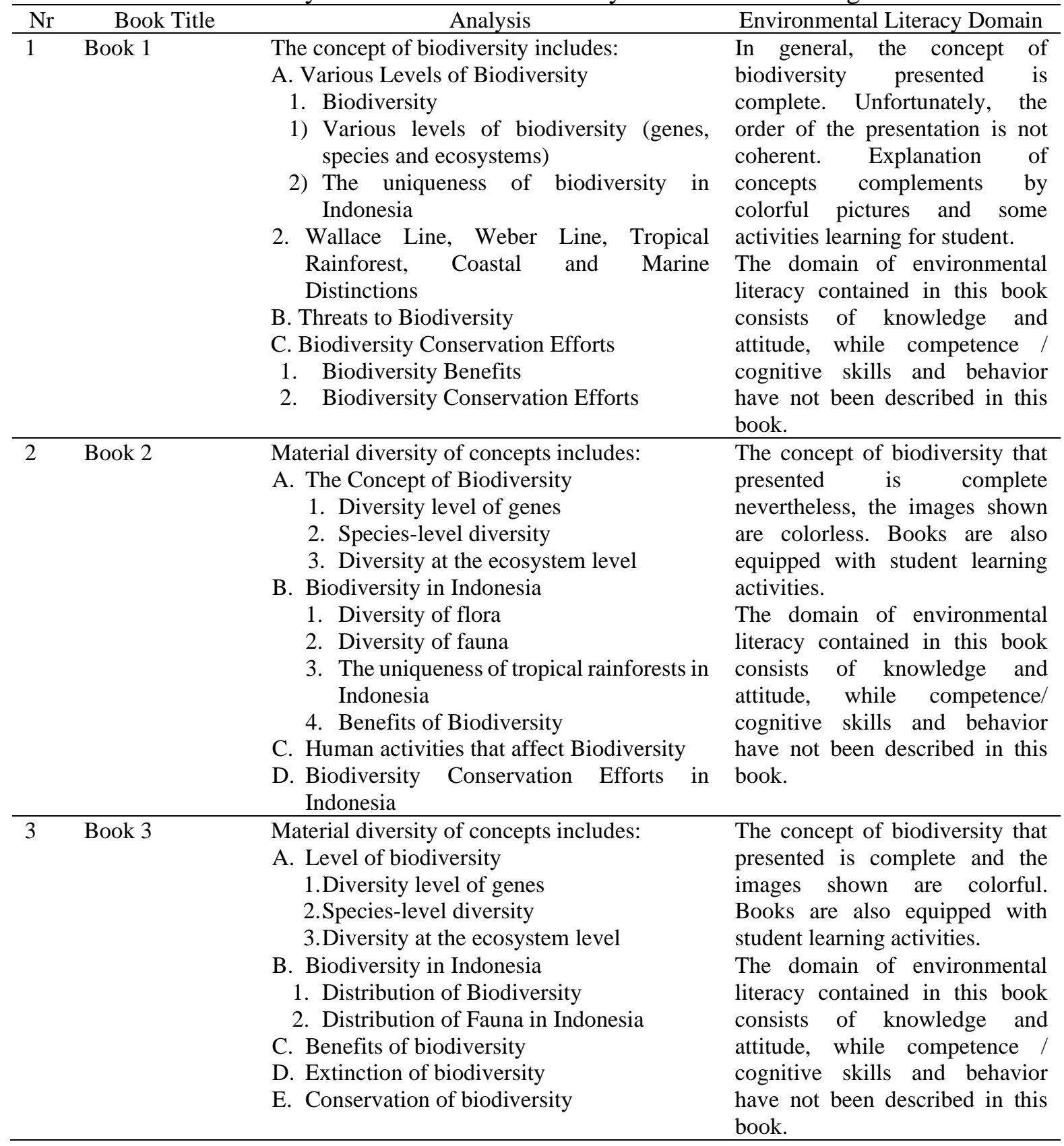

From Table 3 it is known that the concept of biodiversity has been presented in full according to the required competencies in the curriculum. Concept presentation starts from biodiversity at the level of genes, species and ecosystems, threats to biodiversity and conservation efforts. It was also presented that climate change is a factor in the loss of biodiversity. Furthermore, in the three books, there is no explanation regarding individual 
efforts to behave and behave towards the environment that contributes to the preservation of biodiversity.

Refers to the four EL domains consisting of knowledge, cognitive skills (identification of issues, analysis of cases, and action plans), attitude (verbal commitment, environmental sensitivity, and feelings towards the environment), and responsible behavior towards the environment. The literature books analyzed focus on the domain of knowledge and attitude, while the fields of cognitive skills and accountable behavior have not been noticed in the book. This finding is in line with (Karimzadegan \& Meiboudia, 2012) which shows that the EL domains in elementary school books are not fully covered. Therefore, in this study, EE was implemented with an e-booklet that provided the EL domain in the biodiversity context of Gegas Dam which has 21 local fish species.

Using real context in e-booklets can increase people to read. Semuan domain EL disajikan dalam e-booklet. Besides the domain of knowledge and cognitive skills, the field of attitude and behavior responsible for the environment is present in the e-booklet. It aims to provide examples and inspiration for readers in protecting the environment. In line with the research results disclosed by (Imtihana, 2014; Keller et al., 2019; Lestari \& Sriyati, 2018; Sulaiman et al., 2018). In addition, the results of research by (Hooykaas et al., 2019) suggest that biodiversity-based e-booklets able to increase species literacy in familiar people of various ages and education levels to be optimistic about nature and animals.

\section{Biodiversity in Gegas Dam and Its Development in E-Booklet}

Biodiversity data in the Gegas Dam consisting of diversity, homogeneity, and dominance indices of fish are present in Table 4.

Table 4. Diversity Index, Evenness Index of Fish Species and Dominance in Air Gegas Dam

\begin{tabular}{ccccc}
\hline \multirow{2}{*}{ Code } & \multicolumn{3}{c}{ Sum } & \multirow{2}{*}{ Total } \\
\cline { 2 - 4 } $\mathbf{S}$ & station I & station II & station III & \\
\cline { 2 - 4 } $\mathbf{F}$ & $17^{*}$ & 6 & 13 & 21 \\
\hline $\mathbf{N}$ & 338 & 2 & 4 & 10 \\
$\mathbf{H}$ & $2,01^{*}$ & 1,04 & $404^{*}$ & 984 \\
$\mathbf{E}$ & $0,66^{*}$ & 0,34 & 1,74 & 1,59 \\
$\mathbf{C}$ & 0,18 & $0,25^{*}$ & 0,57 & 0,52 \\
& & 0,19 & 0,20 \\
\hline
\end{tabular}

$\mathrm{S}=$ types; $\mathrm{F}=$ family; $\mathrm{N}=$ individual $; \mathrm{H}^{\prime}=$ diversity index; $\mathrm{E}=$ homogeneity; $\mathrm{C}=$ dominance; $*$ = highest score

Table 4 Shows that the most significant number of species and families, homogeneity, and diversity index is Station 1. Characteristics of water habitat determine diversity of freshwater fish. Habitat characteristics in lakes are influenced by river flows, presence of forests or plants along lake. Measurement of water physical and chemical parameters showed a pH of 6.8; water temperature $31^{\circ} \mathrm{C}$, turbidity $6.90 \mathrm{NTU}$, brightness $75 \mathrm{~cm}$, BOD $2.1 \mathrm{mg} / \mathrm{l}$, COD $17.018 \mathrm{mg} / \mathrm{l}$, and DO $6.17 \mathrm{mg} / \mathrm{l}$. Based on the water quality standards, the water quality at station 1 meets the water quality standards required for freshwater fish fisheries.

Based on the analysis of the diversity index and water quality data, the next activity is to develop a biodiversity e-booklet based on real context Gegas Dam and also an EL domain test. E-booklet contains El domain knowledge, cognitive skills (identification of issues, analysis of cases, and action plans), attitude (verbal commitment, environmental sensitivity, and feelings 
towards the environment), and responsible behavior towards the environment. Each component is present in Figure 2.
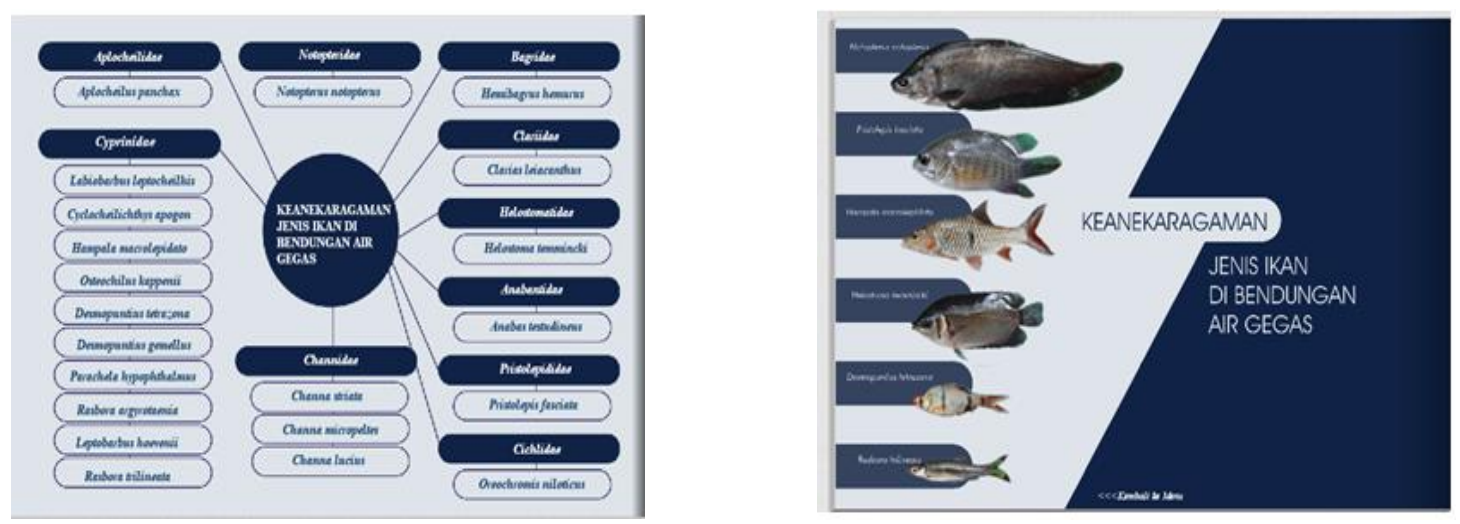

Figure 2a. Display Domain Knowledge in E-booklet

McBeth \& Volk (2009) suggested that domain knowledge focuses on knowledge about the environment or knowledge of ecology. Referring to this definition, this domain in the e-booklet presents basic concepts about ecosystems and focusing on aquatic ecosystems, and more focusing on fish.
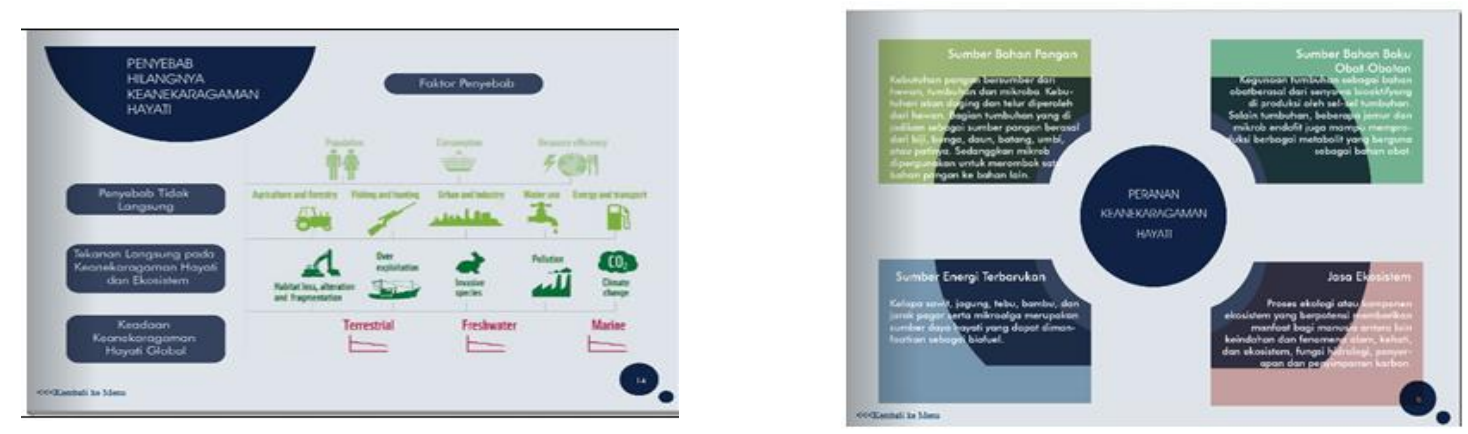

Figure 2b. Display Domain Cognitive Skills in E-booklet

The cognitive skills domain focuses on the identification of issues, analysis of problems and action plans. Therefore, in this e-booklet, several cases regarding the environment are presented with the aim that students can identify and analyze issues related to the environment and are able to plan actions to protect the environment.
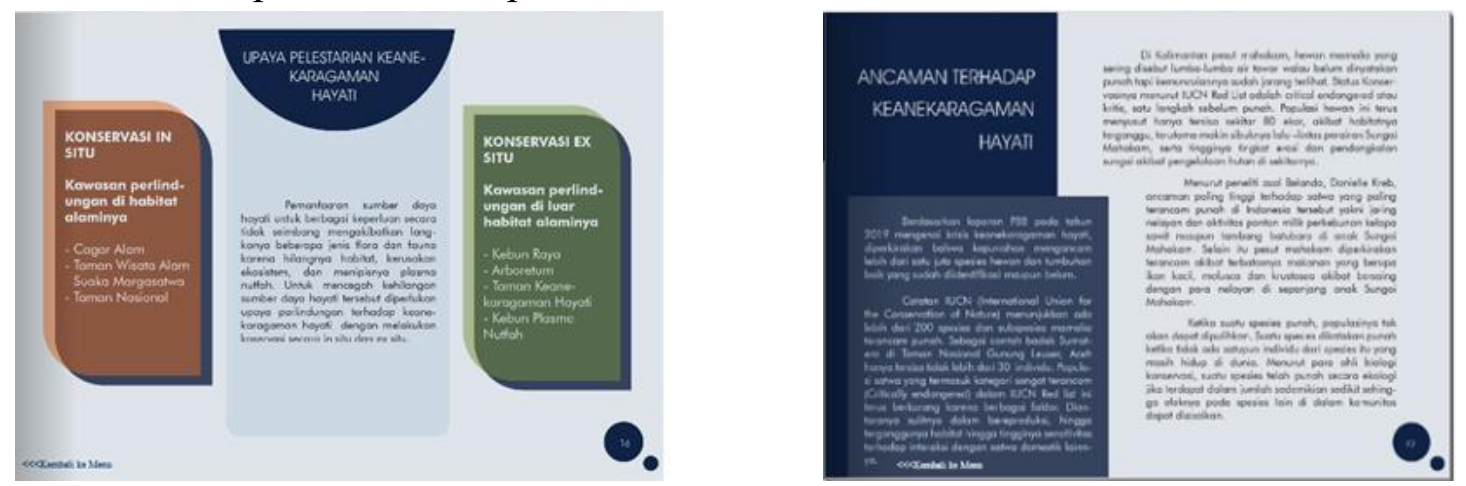

Figure 2c. Display Domain Attitude in E-booklet 
The attitude domain focuses on verbal commitment, environmental sensitivity, and feelings towards the environment. Therefore in this e-module several topics are presented on threats to the environment and efforts to conserve biodiversity.
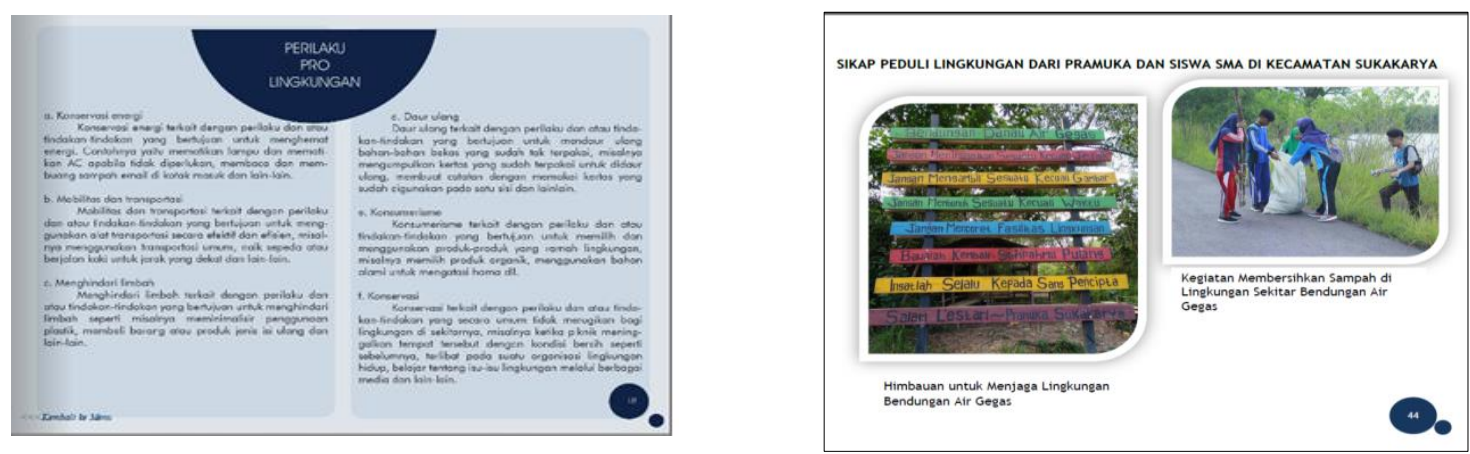

Figure 2d. Display Domain Pro-Environmental in E-booklet

The domain of pro-environmental behavior focuses on real applications or actions that implement knowledge, cognitive skills, attitudes, and pro-environment. Therefore, in this ebooklet, real examples of pro-environmental behavior are presented.

Referring to the entire e-booklet that provides the EL domain, it expects that this e-bookletassisted EE will contribute to conservation and environmental quality outcomes, considering $\mathrm{EE}$ is a knowledge transformation and must provide attitudes and skills to protect the environment (Ardoin et al., 2020)

\section{Students' Environmental Literacy}

Students' environmental literacy is measured based on the components of the EL domain knowledge, cognitive skills, attitude, and behavior -. The n-gain score of each EL domain presents in Table 5.

Table 5. Average Pretest, Posttest and n-gain Environmental Literacy

\begin{tabular}{|c|c|c|c|c|c|}
\hline $\begin{array}{l}\text { Environmental } \\
\text { Literacy } \\
\text { Domain }\end{array}$ & Specific Component & $\begin{array}{l}\text { Pre- } \\
\text { test }\end{array}$ & Post-test & n-Gain & Categorize \\
\hline Knowledge & Biodiversity knowledge & 43,17 & 65,67 & 0,40 & Medium \\
\hline \multirow[t]{5}{*}{ Attitude } & Verbal commitment & 87 & 95 & 0,62 & Medium \\
\hline & Environmental sensitivity & 73,3 & 78,6 & 0,20 & Low \\
\hline & Environmental feel & 95,67 & 98 & 0,54 & Medium \\
\hline & Average & 85,32 & $\mathbf{9 0 , 5 3}$ & $\mathbf{0 , 3 5}$ & Medium \\
\hline & Identification of Issue & 39 & 53,33 & 0,23 & Low \\
\hline \multirow{3}{*}{ Competences } & Action plan & 63,33 & 76,67 & 0,36 & Medium \\
\hline & Analysis of Issue & 36,67 & 61,67 & 0,39 & Medium \\
\hline & Average & 46,33 & 63,89 & $\mathbf{0 , 3 3}$ & Medium \\
\hline Behaviour & Pro Environmental Action & 72 & 84 & 0,43 & Medium \\
\hline \multicolumn{2}{|c|}{ Environmental literacy average } & 61,71 & 76,02 & $\mathbf{0 , 3 7}$ & Medium \\
\hline
\end{tabular}


Table 5 showed that in general there was an increase in EL with n-gain 0.37 (moderate). Students' verbal commitment got the highest n-gain (0.62), while environmental sensitivity ngain was the smallest (0.2). Verbal Commitment related what the individual would be willing to do or intend to do regarding the environment. Knowledge of biodiversity presented in ebooklet, along with cases of extinction caused by human activities, encourages them to improve their commitment toward environmental. These results indicate that verbally students or youth generation already know how to conserve/protect the environment. The cultivation of environmental care habits can be continuously improved by realizing their verbal ideas.

The actual context used in the e-booklet, namely the ecosystem in Gegas Dam provides a unique attraction for students. It makes them commit to maintaining the environment at least verbally. Losing knowledge of local ecosystems and their original biodiversity hinders environmental conservation efforts, in line with the results of research conducted by (Hooykaas et al., 2019) who has researched that generally, the community disconnect from their local ecological knowledge, which prevents them from preserving the environment.

Through an e-booklet that presents the ecosystem in Gegas Dam, which is a playground for young people, it is able to help them explore the entire ecosystem in the dam, this also raises awareness for the younger generation, in line with the results of research (Keller et al., 2019) who stated that through e-booklets that explore local potentials, they can increase awareness of the importance of local and global ecosystems.

Meanwhile, sensitivity is an expression of positive concern and feeling for the environment and has been described by Peterson as a series of positive affective characteristics that produce individuals who are able to see the environment from an empathetic perspective (Hollweg et al., 2011). The low n-gain in the environmental sensitivity component is because sensitivity should be explored through the learning process. Online learning at least reinforces this cultivation of sensitivity. Based on a study conducted by (Fİdan, 2016) that the acquisition of values such as academic honesty, scientific persistence, sensitivity to the natural environment, aesthetics, respect for diversity, sensitivity to cultural heritage, awareness of cultural heritage, self-confidence and responsibility cannot be transfer efficiently to students.

\section{Conclusion}

EE developed in the research was conducted assisted e-booklets which provide EL domainknowledge, cognitive skills attitude and responsible behavior towards the environment-. The ebooklet developed was through research and development design. The e-booklet contains diversity index, homogeneity, dominance and correlation between chemical-physical environmental factors are presented in an e-booklet to strengthen students' knowledge and cognitive skills, while attitude and responsibility behavior are strengthened by presenting local issues, national and global about the environment issues. Students' EL was measured using modified EL instruments. The results showed that in general there was an increase in EL domain with an n-gain of 0.37 (moderate). Students' verbal commitment got the highest n-gain (0.62), while environmental sensitivity n-gain was the smallest (0.2). This shows that the EL domain provided through e-booklets able to increase students' verbal commitment to protecting the environment for the better. 


\section{Acknowledgment}

Thanks and appreciation to the University of Bengkulu for providing funding through the Fundamental research program. We want to thank the Gegas Dam management and the students involved in this research.

\section{References}

Ardoin, N. M., Bowers, A. W., \& Gaillard, E. (2020). Environmental education outcomes for conservation: A systematic review. Biological Conservation, 241(August 2019), 108224. https://doi.org/10.1016/j.biocon.2019.108224

Craig, C. A., \& Allen, M. W. (2015). The impact of curriculum-based learning on environmental literacy and energy consumption with implications for policy. Utilities Policy, 35, 41-49. https://doi.org/10.1016/j.jup.2015.06.011

Fİdan, N. K. (2016). Sensitivity of Students to the Natural Environment, Animals, Social Problems and Cultural Heritage. 8(3), 403-424.

Goldman, D., Baum, D., Ayalon, O., \& Weiss, B. (2018). Influence of Green School Certification on Students Environmental Literacy and Adoption of Sustainable Practice by Schools. Journal of Cleaner Production. https://doi.org/10.1016/j.jclepro.2018.02.176

Goldman, D., Yavetz, B., \& Pe'er, S. (2014). Student teachers' attainment of environmental literacy in relation to their disciplinary major during undergraduate studies. International Journal of Environmental and Science Education, 9(4), 369-383. https://doi.org/10.12973/ijese.2014.222a

Hollweg, K., Taylor, J., Bybee, R., Marcinkowski, T., McBeth, W., \& Zoido, P. (2011). Developing a framework for assessing environmental literacy. North American Association for Environmental Education, 122.

Hooykaas, M. J. D., Schilthuizen, M., Aten, C., Hemelaar, E. M., Albers, C. J., \& Smeets, I. (2019). Identification skills in biodiversity professionals and laypeople: A gap in species

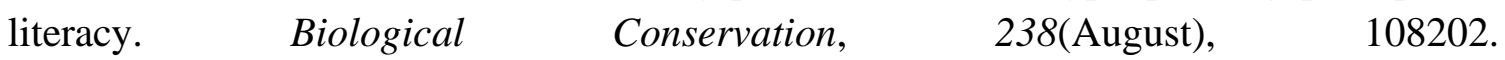
https://doi.org/10.1016/j.biocon.2019.108202

Ismail, M. (2014). The factors causing the declining fish catchees reservat and efforts to improve the function of fresh water fish. Gerbang Etam, 8(2), 4-17.

Imtihana, M., HB, F. P. M., \& Priyono, B. (2014). Pengembangan Buklet Berbasis Penelitian Sebagai Sumber Belajar Materi Pencemaran Lingkingan Di SMA. Journal of Biology Education, 3(2).

Karimzadegan, H., \& Meiboudia, H. (2012). Exploration of Environmental Literacy in Science Education Curriculum in Primary Schools in Iran. Procedia - Social and Behavioral Sciences, 46, 404-409. https://doi.org/10.1016/j.sbspro.2012.05.131

Kaya, V. H., \& Elster, D. (2018). German Students' Environmental Literacy in Science Education Based on PISA Data. Science Education International, 29(2), 75-87. https://doi.org/10.33828/sei.v29.i2.2

Keller, J., Kim, J., Han, Z., \& Zhang, T. (2019). Developing an Educational Booklet for the Delta Nature Reserve to Encourage Public Engagement and Interest in the Plant Biodiversity at Burns Bog. 1-47.

Koneri, R. (2019). Biologi konservasi. Bandung. CV Patra Media Grafindo

Imtihana, M., Martin, F. P., \& Priyono, B. (2014). Pengembangan Buklet Berbasis Penelitian 
Sebagai Sumber Belajar Materi Pencemaran Lingkingan Di Sma. Journal of Biology Education, 3(2), 186-192. https://doi.org/10.15294/jbe.v3i2.4459

Lestari, S., Sriyati, S., \& Amprasto, A. (2018, December).The utilization of e-booklet of plants diversities based on local potency to enhance student's conservation attitudes and skills for classification.In International Conference on Mathematics and Science Education of Universitas Pendidikan Indonesia (Vol. 3, pp. 23-28).

McBeth, W., \& Volk, T. (2009). The national environmental literacy project: A baseline study of middle grade students in the United States. Journal of Environmental Education, 41(1), 55-67. https://doi.org/10.1080/00958960903210031

Ozgurler, S., \& Cansaran, A (2014). Graduate Students, Study of Environmental Literacy and Sustainable Development. International Electronic Journal of Environmental Education, 4(2), 71-83. https://doi.org/10.18497/iejee-green.31036

Saltan, F., \& Divarci, O. F. (2017). European Journal of Educational Research. 6(3), 347355. https://doi.org/10.12973/eu-jer.6.3.347

Saribas, D. (2015). Investigating the Relationship between Pre-Service Teachers 'Scientific Literacy, Environmental Literacy and Life-Long Learning Tendency. 26(1), 80-100.

Saribas, Deniz, Teksoz, G., \& Ertepinar, H. (2014). The Relationship between Environmental Literacy and Self-efficacy Beliefs toward Environmental Education. Procedia - Social and Behavioral Sciences, 116, 3664-3668. https://doi.org/10.1016/j.sbspro.2014.01.820

Shamuganathan, S. (2015). Modeling Environmental Literacy of Malaysian Pre- University Students. 10(5), 757-771. https://doi.org/10.12973/ijese.2015.264a

Srbinovski, M., Erdogan, M., \& Ismaili, M. (2010). Environmental literacy in the science education curriculum in Macedonia and Turkey. Procedia - Social and Behavioral Sciences, 2(2), 4528-4532. https://doi.org/10.1016/j.sbspro.2010.03.725

Sulaiman, M., Ngabekti, S., \& Widiatningrum, T. (2019). The Development of Booklet about the Variety of Macroscopic Fungi Species in Arboretum Sylva Western Borneo as the Supplement of Learning Material at High School. Journal of Innovative Science Education, 8(1), 99-107.

Timur, S., Timur, B., \& Yilmaz, S. (2013). Determining primary school candidate teachers' levels of environmental literacy. Anthropologist, 16(1-2), 57-67. https://doi.org/10.1080/09720073.2013.11891335

Wilujeng, I., Dwandaru, W. S. B., \& Rauf, R. A. B. A. (2019). The effectiveness of education for environmental sustainable development to enhance environmental literacy in science education: A case study of hydropower. Jurnal Pendidikan IPA Indonesia, 8(4), 521-528. https://doi.org/10.15294/jpii.v8i4.19948

Wargasasmita, S (2002). Air tawar endemik sumatra yang terancam punah. Jurnal Iktiologi Indonesia 2(2), 41-49. 